\title{
Synthesis of Isotopically Labeled Anti-HIV Nucleoside Islatravir through a One-Pot Biocatalytic Cascade Reaction
}

\author{
Sumei Ren,* Mark A. Huffman, Aaron M. Whittaker, Hao Yang, Christopher C. Nawrat, David J. \\ Waterhouse, Kevin M. Maloney, and Neil A. Strotman \\ Process Research and Development, Merck \& Co., Inc., Rahway, New Jersey 07065, United States \\ sumei.ren@merck.com
}

Supporting Information

Table of contents

1. General Experimental Details......................................................................................................... 2

2. Chemical de novo Synthesis of $\left[{ }^{14} \mathrm{C}\right]$ Islatravir with HPLC, MS and Calculation Data........................ 3

3. 4-Enzyme Cascade Biocatalysis Synthesis of $\left[{ }^{14} \mathrm{C}\right]$ Islatravir with HPLC, MS and Calculation Data... 10

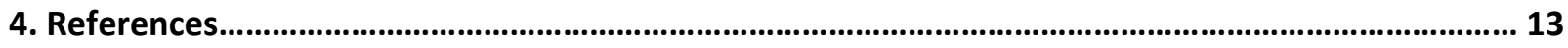




\section{General Experimental Details}

Acetaldehyde-2- ${ }^{14} \mathrm{C}$ was obtained from ViTrax, Inc., Placentia, CA, USA; glyceraldehyde 3-phosphate 10, 2-FA 11 and unlabeled islatravir were prepared according to references. ${ }^{1,2}$ all the enzymes have been repoted $^{2}$ and were obtained from either Asymchem, Inc. Morrisville, NC, USA, or from Codexis, Inc., Redwood City, CA, USA. All other reagents and solvents were from commercially available sources and used without any further purification.

${ }^{14} \mathrm{C}$ radioactivity was measured in a PerkinElmer Ultra Gold liquid scintillation cocktail with a PerkinElmer 3110TR liquid scintillation analyzer. The UV purities of the ${ }^{14} \mathrm{C}$-labeled compounds were determined by analytical RP-HPLC conducted with an Agilent 1200 series. Prep-RP-HPLC was performed on an Agilent 1100 system. ${ }^{14} \mathrm{C}$ radioactivity was measured with either PerkinElmer Radiomatic 625TR Flow Scintillation Analyzer or Lablogic Laura Beta-Ram 5 flow detector using PerkinElmer Ultra Gold liquid scintillation cocktail at $3 \mathrm{~mL} / \mathrm{min}$.

The first-generation chemical synthesis of $\left[{ }^{14} \mathrm{C}\right]$ Islatravir was conducted with the assistance of Moravek Biochemicals, Inc., Brea, CA, USA.

\section{RP-HPLC Analytical Methods}

HPLC system 1: Ascentis Express C18, $4.6 \times 150 \mathrm{~mm}, 2.7 \mu \mathrm{m}, 40^{\circ} \mathrm{C}, 1.5 \mathrm{~mL} / \mathrm{min}, 204 \mathrm{~nm}$, elutes with $2 \%$ to $8 \% \mathrm{~B}$ in $15 \mathrm{~min}$, then increase to $30 \% \mathrm{~B}$ in $15 \mathrm{~min}$. Mobile Phase A: Water w/ 0.1\% Formic acid, B: ACN $\mathrm{w} / 0.1 \%$ Formic acid.

HPLC system 2: Atlantis T3 column, $4.6 \times 150 \mathrm{~mm}, 3 \mu \mathrm{m}, 40^{\circ} \mathrm{C}, 1.0 \mathrm{~mL} / \mathrm{min}, 265 \mathrm{~nm}$, elutes with $2 \% \mathrm{~B}$, $98 \% \mathrm{~A}$ for $2 \mathrm{~min}, 2 \% \mathrm{~B}$ to $80 \% \mathrm{~B}$ in $6 \mathrm{~min}$, hold for $2 \mathrm{~min}$ then increase to $95 \% \mathrm{~B}$ in $2 \mathrm{~min}$, hold for $3 \mathrm{~min}$. A: Water w/0.05\% TFA, B: ACN.

\section{Prep-RP-HPLC Method}

Phenomenex PFP (2), $21.2 \times 250 \mathrm{~mm}$, eluting with $25 \%$ Methanol $/ 75 \%$ water, $254 \mathrm{~nm}, 5.0 \mathrm{~mL} / \mathrm{min}$. The compound eluted at $76 \mathrm{~min}$.

\section{HPLC-MS Method}

HPLC-MS analyses were performed on an Agilent 1260 infinity instrument in API-ES positive mode. HPLC conditions: Agilent Poroshell 120 EC C18 column, $3.0 \times 50$ mm, $2.7 \mu \mathrm{m}, 40^{\circ} \mathrm{C}, 1 \mathrm{~mL} / \mathrm{min} ; 90 \% \mathrm{~A}: 10 \% \mathrm{~B}$ to $95 \% B$ over $5.2 \mathrm{~min}$ and hold for $0.8 \mathrm{~min}$. A: $0.1 \%$ aqueous formic acid, B: ACN.

\section{TLC analyses:}

Analytical thin layer chromatography (TLC) was performed on silica gel 60 F254 glass TLC plates.

\section{Total Protein Content Testing Method}

Samples at $1 \mathrm{mg} / \mathrm{ml}$ in 75:25 $\mathrm{H}_{2} \mathrm{O}: \mathrm{ACN}$ were prepared. These samples were run via USP $<507>$ Method III Bradford Assay on a plate reader format ( $50 \mu \mathrm{L}$ samples/stds, $200 \mu \mathrm{L}$ dye). Standards used were: $2.5,5$, $10,15,20$, and $25 \mu \mathrm{g} / \mathrm{ml} \mathrm{BSA}$ in diluent. measure absorbance at $595 \mathrm{~nm}$. 


\section{Chemical de novo Synthesis of $\left[{ }^{14} \mathrm{C}\right]$ lslatravir}
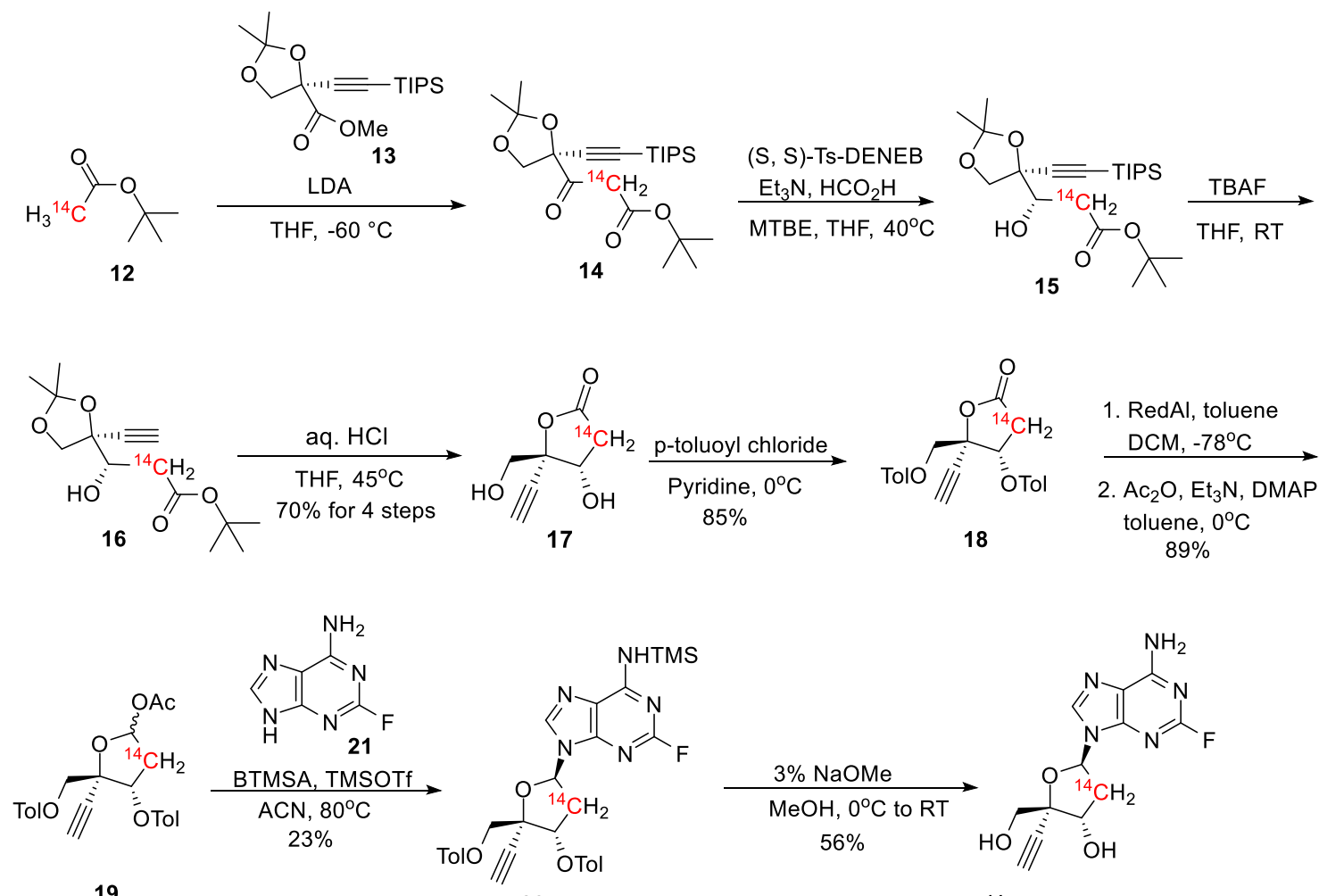

19

$\left[{ }^{14} \mathrm{C}\right]$ islatravir, 1

\section{Synthetic Procedures}

All the products except for the final product were analyzed by TLC through comparison with authentic unlabeled reference intermediates.

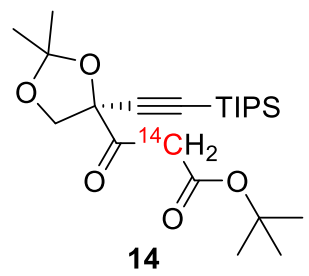

To a cooled $\left(-20^{\circ} \mathrm{C}\right)$ solution of diisopropylamine $(0.84 \mathrm{~mL}, 6.0 \mathrm{mmol})$ in anhydrous THF $(6 \mathrm{~mL})$ under $\mathrm{N}_{2}$ was added a $\mathrm{N}$-butyllithium solution $(2.0 \mathrm{~mL} ; 2.5 \mathrm{M}$ in hexanes, $5.0 \mathrm{mmol})$ over 5 minutes. The reaction solution was stirred at $-20^{\circ} \mathrm{C}$ for 20 minutes, then further cooled to $-78{ }^{\circ} \mathrm{C}$ and stirred for $10 \mathrm{~min}$. A solution of tert-butyl acetate- $2-{ }^{14} \mathrm{C} 12(150 \mathrm{mCi}, 50 \mathrm{mCi} / \mathrm{mmol}, 3.0 \mathrm{mmol})$ in THF $(2 \mathrm{~mL})$ was added to the reaction over 5 minutes and aged at $-78^{\circ} \mathrm{C}$ for 1 hour. Finally, compound $13(1.02 \mathrm{~g}, 3.0 \mathrm{mmol}$, in 3.0 $\mathrm{mL}$ of THF) was added over 5 minutes. The reaction was stirred at $-78^{\circ} \mathrm{C}$ for $1 \mathrm{~h}$ until no compound 13 remained by $\mathrm{TLC}$ analysis $\left(\mathrm{CH}_{2} \mathrm{Cl}_{2}\right.$ on $\left.\mathrm{SiO}_{2}\right)$. The reaction was quenched by dropwise addition of acetic acid $(0.43 \mathrm{~mL})$ at $-78{ }^{\circ} \mathrm{C}$, dilution with MTBE $(10 \mathrm{~mL})$, then warmed to room temperature (RT). The mixture was sequentially washed with aqueous citric acid $(10 \% ; 15 \mathrm{~mL})$, aqueous sodium bicarbonate $(5$ 
$\% ; 10 \mathrm{~mL})$, and brine $(10 \mathrm{~mL})$. The resulting organic solution containing crude product 14 was used in the next step directly.

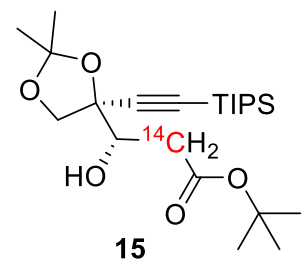

The solution of compound 14 in a $100 \mathrm{~mL}$ round bottom flask was sparged with $\mathrm{N}_{2}$, then (S, S)-Ts-DENEB catalyst ( $10 \mathrm{mg}, 0.015 \mathrm{mmol}$ ) was added at RT. To the resulting solution, a solution of triethylammonium formate, which was prepared from triethylamine $(0.42 \mathrm{~mL}, 4.0 \mathrm{mmol})$ and formic acid $(0.28 \mathrm{~mL}, 7.0$ $\mathrm{mmol})$ in THF ( $3 \mathrm{~mL})$, was added. The reaction mixture was stirred at $40{ }^{\circ} \mathrm{C}$ for 5 hours and TLC analysis $\left(\mathrm{CH}_{2} \mathrm{Cl}_{2}\right.$ on $\left.\mathrm{SiO}_{2}\right)$ showed no starting material remained with clean conversion to the desired product. The reaction mixture was cooled to RT and diluted with MTBE $(25 \mathrm{~mL})$. The mixture was washed sequentially with aqueous citric acid $(10 \% ; 10 \mathrm{~mL})$ and brine $(10 \mathrm{~mL})$. The organic phase was concentrated under reduced pressure to yield compound $\mathbf{1 5}$ as an amber solid. The crude product was used as-is in the next reaction.

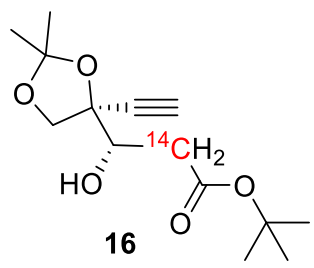

To a solution of compound 15 in THF ( $8 \mathrm{~mL}$ ), was added tetrabutylammonium fluoride (TBAF, $3 \mathrm{~mL} ; 1.0$ $\mathrm{M}$ in THF, $3.0 \mathrm{mmol}$ ) and stirred at RT for 40 minutes. TLC analysis ( $1 \% \mathrm{MeOH}$ in $\mathrm{CH}_{2} \mathrm{Cl}_{2}$ on $\mathrm{SiO}_{2}$ ) showed no starting material remained. The reaction was quenched with water $(10 \mathrm{~mL})$ and diluted with MTBE $(20 \mathrm{~mL})$. The organic layer was washed with brine $(10 \mathrm{~mL})$ and concentrated under reduced pressure to give compound $\mathbf{1 6}$ as an amber residue. The crude product was used as-is in the next step.

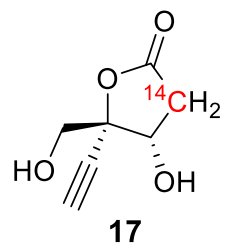

To a solution of the compound 16 in THF $(11 \mathrm{~mL})$ was added $\mathrm{HCl}(37 \%, 0.75 \mathrm{~mL}, 9.0 \mathrm{mmol})$ dropwise at RT. The resulting mixture was warmed to $45^{\circ} \mathrm{C}$ and stirred for 2 hours. TLC analysis $\left(1 \% \mathrm{MeOH}\right.$ in $\mathrm{CH}_{z} \mathrm{Cl}_{2}$ on $\mathrm{SiO}_{2}$ ) showed no starting material remained. The mixture was cooled to $\mathrm{RT}$ and concentrated under reduced pressure to give the crude product as an amber residue. The residue was dissolved in isopropyl acetate $(3 \mathrm{~mL})$ at RT and stirred for $2 \mathrm{~h}$. The resulting solid was filtered, washed with isopropyl acetate (2 $x 0.5 \mathrm{~mL})$, and dried under high vacuum to give the desired lactone 17 as a tan solid $(0.3306 \mathrm{~g}, 105 \mathrm{mCi}$, $70 \%$ yield for 4 steps from compound 12 ). 


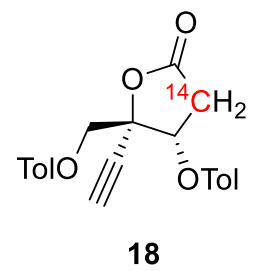

To a solution of the lactone $17(105 \mathrm{mCi}, 2.1 \mathrm{mmol})$ in pyridine $(2.0 \mathrm{~mL})$ was added $p$-toluoyl chloride $(0.58 \mathrm{ml}, 4.0 \mathrm{mmol})$ at $0{ }^{\circ} \mathrm{C}$ over 5 minutes. The resulting mixture was stirred for 2 hours at $0{ }^{\circ} \mathrm{C}$. Water $(3 \mathrm{ml})$ was added slowly and causing solid product to precipitate over a few minutes. Citric acid (10\%; 10 $\mathrm{mL}$ ) was added and the resulting mixture was extracted with $\mathrm{CH}_{2} \mathrm{Cl}_{2}(2 \times 20 \mathrm{~mL})$. The organic phase was concentrated under reduced pressure to give the crude 18 as an amber residue. The crude product was purified by flash chromatography on silica gel eluting with gradient 50 to $100 \% \mathrm{CH}_{z} \mathrm{Cl}_{2}$ in hexanes. Fractions containing product were combined and concentrated to a white solid which was further purified by recrystallization. The solid was dissolved in MTBE $(20 \mathrm{~mL})$ at $30^{\circ} \mathrm{C}$. Hexanes $(35 \mathrm{ml})$ were added slowly. The mixture was concentrated on a rotary evaporator to $\sim 20 \mathrm{~mL}$ causing solid to precipitate. The solid was filtered, washed with hexanes $(3 \times 2 \mathrm{~mL})$, and dried under high vacuum to give compound 18 (0.6996 g, $89 \mathrm{mCi}, 85 \%)$ as a white solid.

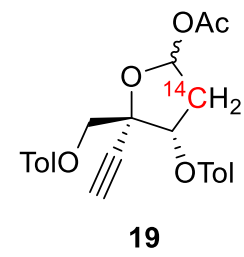

To a solution of compound 18 (89 $\mathrm{mCi}, 1.78 \mathrm{mmol})$ in toluene $(11 \mathrm{~mL})$ and $\mathrm{CH}_{2} \mathrm{Cl}_{2}(5 \mathrm{~mL})$ was added sodium bis(2-methoxyethoxy)aluminum hydride solution in toluene (Red-Al, $0.51 \mathrm{~mL}, 67 \%$ in toluene, $3.0 \mathrm{mmol}$ ) dropwise with stirring at $-70{ }^{\circ} \mathrm{C}$ over 5 minutes under $\mathrm{N}_{2}$. The reaction was stirred at the same condition for 1 hour. TLC analysis $\left(\mathrm{CH}_{2} \mathrm{Cl}_{2}\right.$ on $\left.\mathrm{SiO}_{2}\right)$ showed no starting material remained. The reaction was quenched by slow addition of acetic acid $(1.1 \mathrm{~mL}, 19.2 \mathrm{mmol})$ at $-78^{\circ} \mathrm{C}$, then warmed to $\mathrm{RT}$. The resulting mixture was diluted with MTBE $(25 \mathrm{~mL})$ and the organic phase was sequentially washed with $\mathrm{HCl}(1 \mathrm{~N} ; 20 \mathrm{~mL})$ and saturated sodium bicarbonate $(10 \mathrm{~mL})$. The organic phase was concentrated under vacuum to dryness. The resulting residue was dissolved in toluene $(8 \mathrm{~mL})$ and cooled to $0{ }^{\circ} \mathrm{C} .4$ (dimethylamino)pyridine $(48.9 \mathrm{mg}, 0.4 \mathrm{mmol})$ and triethylamine $(0.39 \mathrm{~mL}, 4.0 \mathrm{mmol})$ were added. The mixture was maintained below $5^{\circ} \mathrm{C}$. Acetic anhydride $(0.33 \mathrm{~mL}, 2.4 \mathrm{mmol})$ was then added over 5 minutes. The mixture was stirred for additional 2 hours at $0{ }^{\circ} \mathrm{C}$ then quenched with water $(0.5 \mathrm{~mL})$ over 5 minutes. The reaction mixture was warmed to RT and MTBE $(25 \mathrm{~mL})$ was added. The reaction mixture was sequentially washed with citric acid $(20 \% ; 20 \mathrm{~mL})$ and sodium bicarbonate $(10 \mathrm{~mL})$. The organic phase was concentrated under reduced pressure to give the crude product as a light-yellow residue. The crude product was purified by flash chromatography on silica gel using $\mathrm{CH}_{2} \mathrm{Cl}_{2}$ as the eluent. Fractions containing the desired product were combined and concentrated under reduced pressure to give compound 19 (79 $\mathrm{mCi}, 89 \%)$ as a colorless viscous residue. 


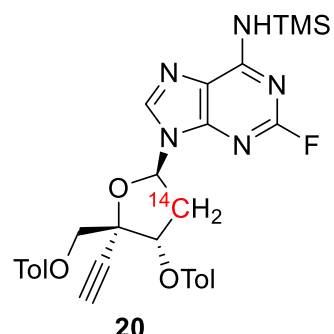

To a slurry of 2-Fluoroadenine 11 (2-FA, $0.322 \mathrm{~g}, 2.0 \mathrm{mmol})$ in ACN (12 mL) was added N, O-

bis(trimethylsilyl)acetamide $(3.09 \mathrm{~mL}, 13 \mathrm{mmol})$. The mixture was stirred at RT for 90 minutes and all the solid was dissolved. The solution was concentrated under reduced pressure leaving a solid residue. To the residue was added a solution of the compound 19 (79 $\mathrm{mCi}, 1.58 \mathrm{mmol}$ ) in 1,2-dichloroethane (12 $\mathrm{mL}$ ). The resulting cloudy mixture was treated with trimethysilyl triflate (TMSOTf, $0.69 \mathrm{~mL}, 4.0 \mathrm{mmol}$ ) and the resulting solution was stirred at $80^{\circ} \mathrm{C}$ overnight. The solvent was removed under reduced pressure leaving a viscous oil. The residue was dissolved in $\mathrm{ACN}(3.5 \mathrm{~mL})$ and stirred at $5^{\circ} \mathrm{C}$ for 1 hour while the solid gradually formed. The solid was filtered, washed with ACN $(2 \times 0.5 \mathrm{~mL})$, and dried under high vacuum to give compound $20(0.2165 \mathrm{~g}, 17.9 \mathrm{mCi}, 23 \%)$ as a white solid.

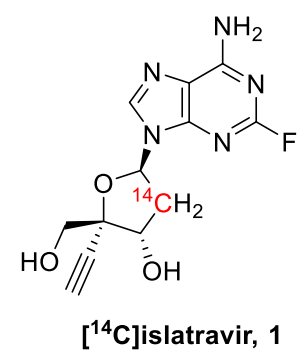

To a cooled $\left(0^{\circ} \mathrm{C}\right)$ solution of compound $20(17.9 \mathrm{mCi}, 0.36 \mathrm{mmol})$ in THF $(2.2 \mathrm{~mL})$ was added sodium methoxide stock solution in methanol $(1.03 \mathrm{ml}, 0.01 \mathrm{M}, 0.01 \mathrm{mmol})$ over 1 hour. The sodium methoxide solution $(0.01 \mathrm{M})$ stock solution was prepared from dilution of $0.1 \mathrm{~mL}$ of sodium methoxide $(0.5 \mathrm{M})$ in methanol with anhydrous methanol $(4.9 \mathrm{~mL})$. The reaction was warmed to RT and stirred overnight. TLC (10\% $\mathrm{MeOH}$ in $\mathrm{CH}_{2} \mathrm{Cl}_{2}$ on $\mathrm{SiO}_{2}$ ) showed no desired product probably due to some water present in the reaction. Additional sodium methoxide ( $0.5 \mathrm{M} ; 3$ drops) was added and stirred at RT overnight. TLC showed the reaction was complete. The reaction was quenched with acetic acid $(25 \mu \mathrm{L})$ and the solvent was removed under reduced pressure. The crude product was purified by flash chromatography on silica gel using 0 to $10 \% \mathrm{MeOH} / \mathrm{CH}_{2} \mathrm{Cl}_{2}$ as the eluent, the fractions containing product were combined and concentrated under reduced pressure to give the product as a white solid. The crude product was further purified by Prep RP-HPLC to give the final $\left[{ }^{14} \mathrm{C}\right]$ islatravir $(10.0 \mathrm{mCi})$ in $56 \%$ radiochemical yield (RCY) with $99.5 \%$ radiochemical purity (RCP) by analytical HPLC 1 system. The specific activity is 49.7 $\mathrm{mCi} / \mathrm{mmol}$ calculated form the MS data. The compound was stored as ethanol solution (10 $\mathrm{mCi}$ in 19.4 $\mathrm{mL})$ at $-80^{\circ} \mathrm{C} .^{3}$ 


\section{Analytical data}

HPLC/ UV trace for authentic unlabeled islatravir by HPLC system 1

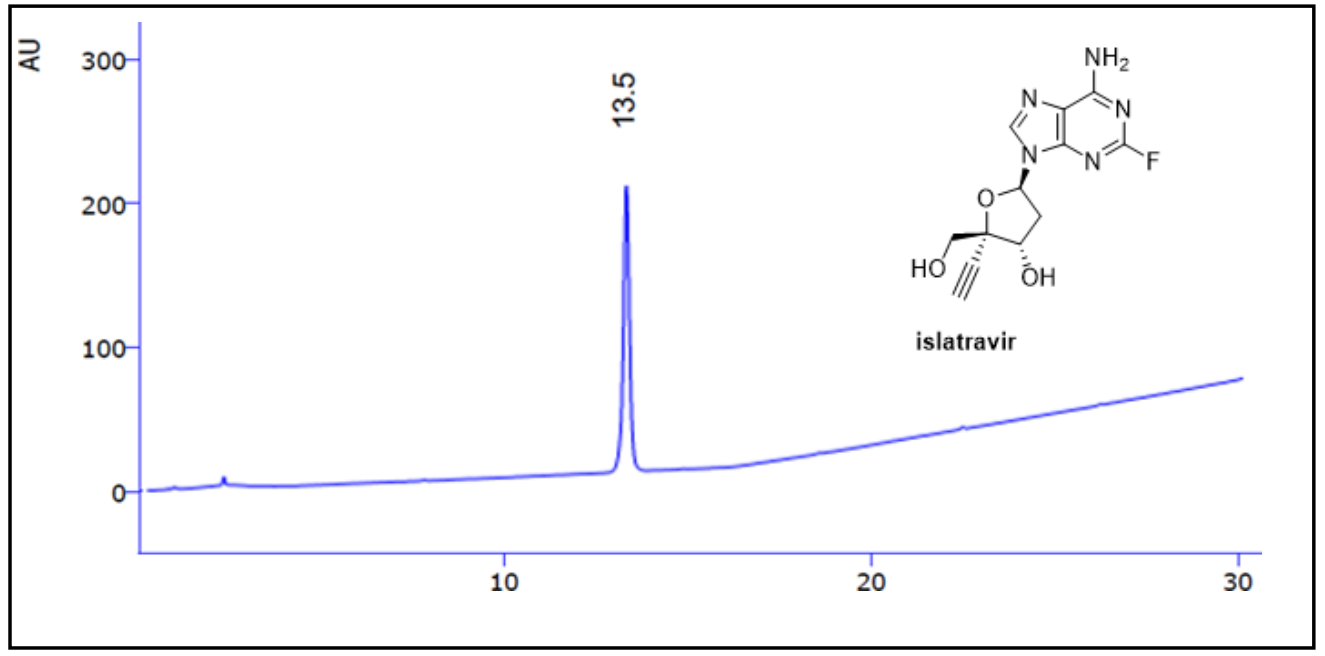

Radio-HPLC/ Radioactivity trace $\left[{ }^{14} \mathrm{C}\right]$ islatravir

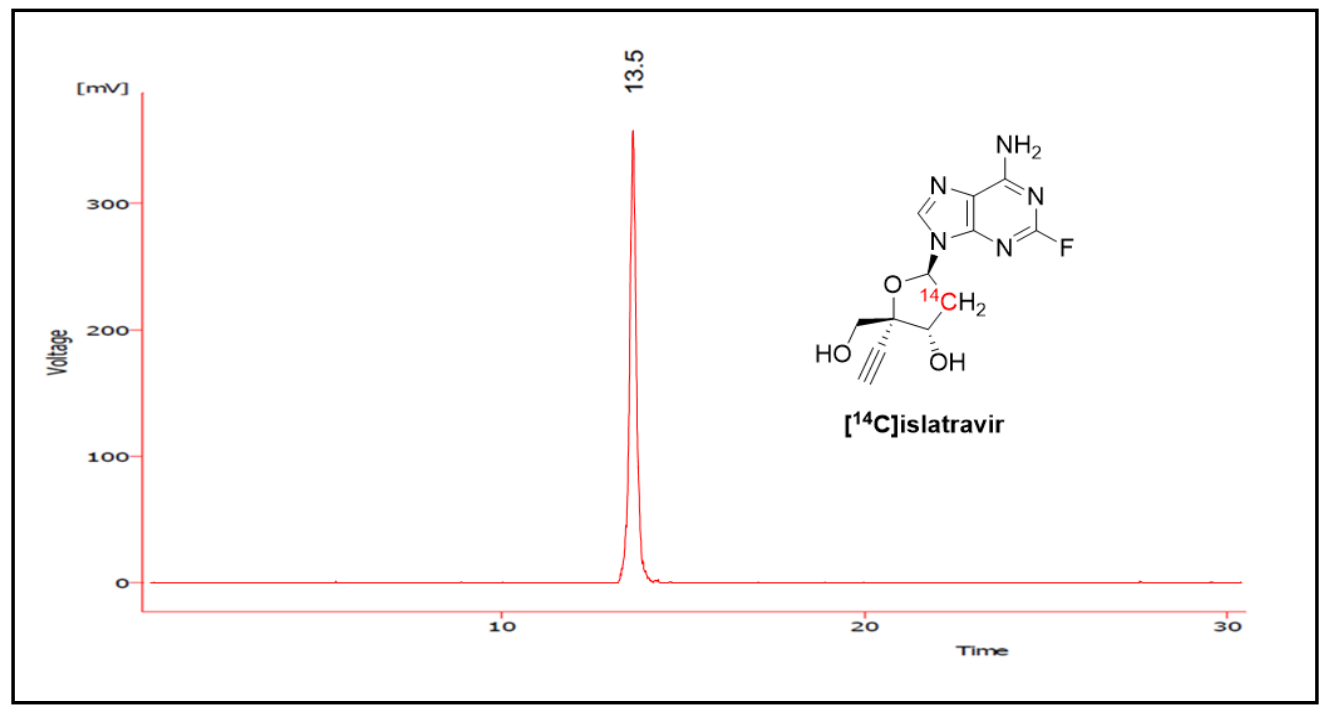

\begin{tabular}{|c|c|c|c|c|c|c|}
\hline & $\begin{array}{l}\text { Reten. Time } \\
{[\mathrm{min}]}\end{array}$ & $\begin{array}{c}\text { Area } \\
{[\mathrm{mV} . \mathrm{s}]}\end{array}$ & $\begin{array}{c}\text { Height } \\
{[\mathrm{mV}]}\end{array}$ & $\begin{array}{l}\text { Area } \\
{[\%]}\end{array}$ & $\begin{array}{c}\text { Height } \\
{[\%]}\end{array}$ & $\begin{array}{c}\text { W05 } \\
{[\mathrm{min}]}\end{array}$ \\
\hline 1 & 13.472 & 4354.628 & 329.596 & 99.52 & 98.2 & 0.19 \\
\hline 2 & 13.736 & 7.912 & 3.760 & 0.18 & 1.1 & 0.04 \\
\hline 3 & 14.172 & 13.171 & 2.434 & 0.30 & 0.7 & 0.02 \\
\hline & Total & 4375.711 & 335.790 & 100.00 & 100.0 & \\
\hline
\end{tabular}




\section{MS data of $\left[{ }^{14} \mathrm{C}\right]$ islatravir and reference}
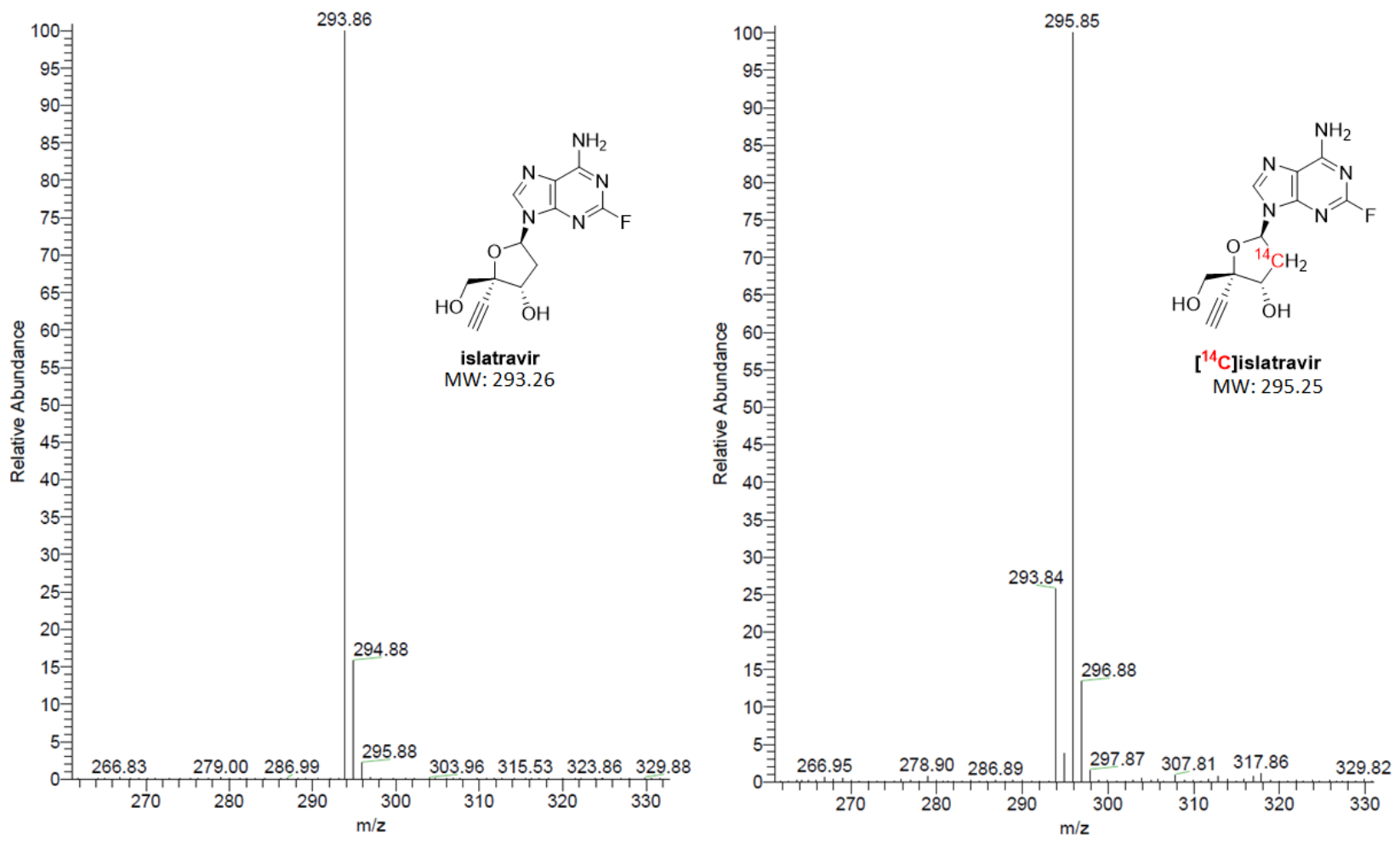


\section{Specific activity of $\left[{ }^{14} \mathrm{C}\right]$ islatravir which calculated from MS data}

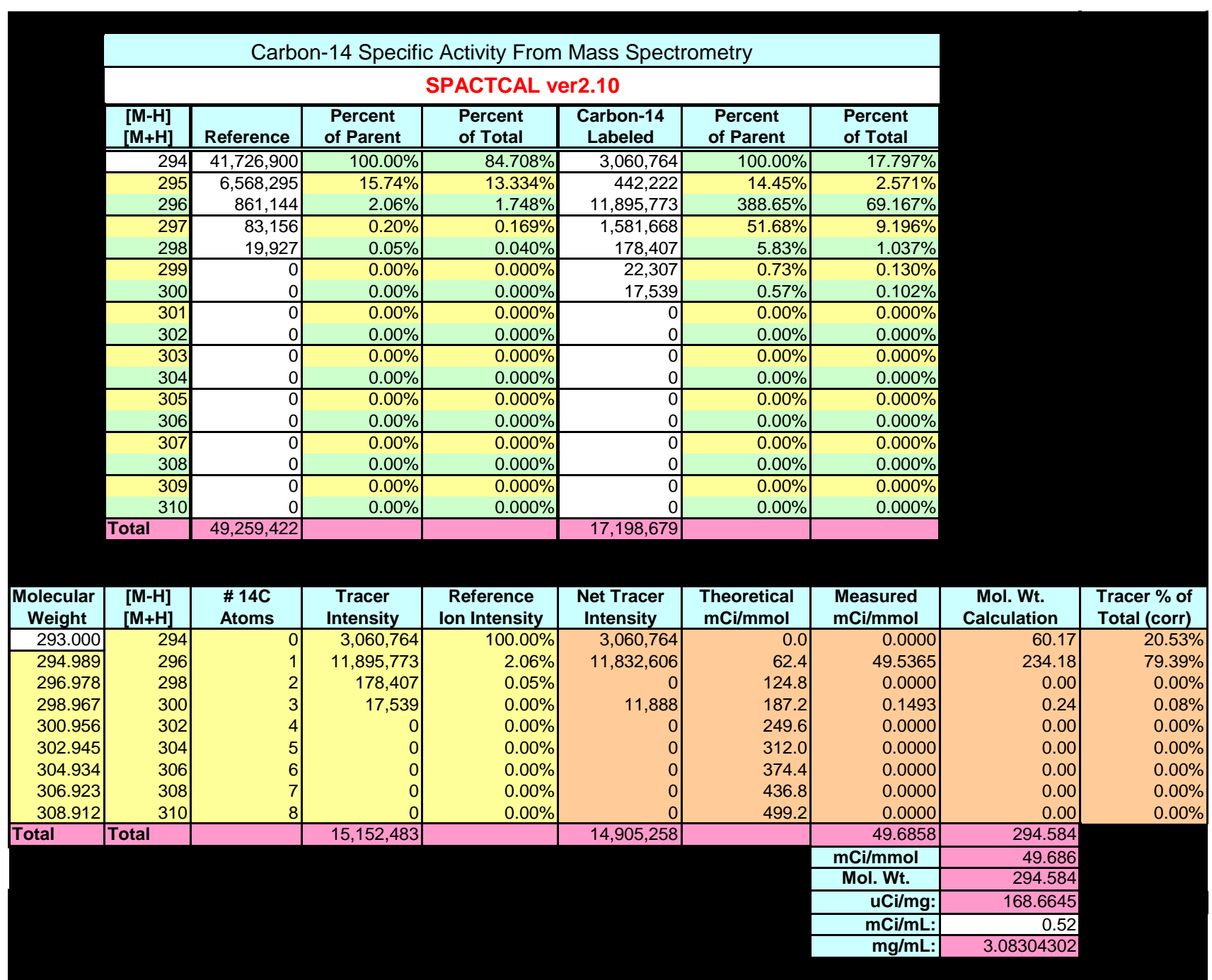




\section{4-Enzyme Cascade Biocatalysis Synthesis of $\left[{ }^{14} \mathrm{C}\right]$ slatravir}

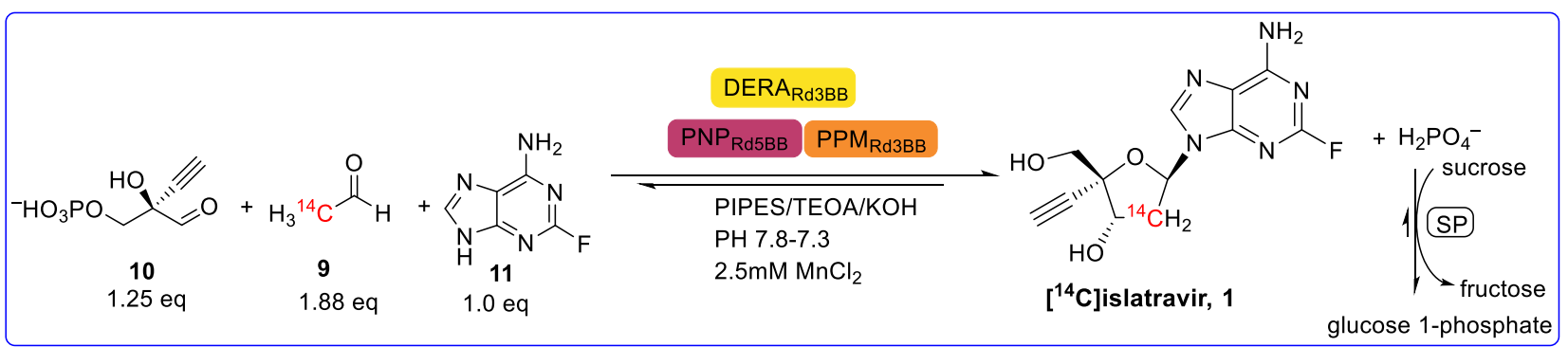

Evolved enzymes

DERA $A_{\text {Rd3BB }}$ evolved Deoxyribose-5-Phosphate Aldolase from Shewanella halifaxensis

$\mathrm{PPM}_{\mathrm{Rd} 3 \mathrm{BB}}$ evolved Phosphopentomutase from $E$. coli

$\mathrm{PNP}_{\mathrm{Rd5BB}}$ evolved Purine Nucleoside Phosphorylase from E. coli
Auxiliary enzymes

Sucrose Phosphorylase from Alloscardovia omnicolens

BB denotes back-bone of the respective evolution round

\section{Synthetic procedure for $\left[{ }^{14} \mathrm{C}\right]$ islatravir using 4-enzyme cascade biocatalysis}

To a $40 \mathrm{~mL}$ glass vial with a stir bar was added the aldehyde phosphate 10 ( $3.6 \mathrm{~mL}, 171 \mathrm{mM}, 0.61 \mathrm{mmol}$, in $50 \mathrm{mM}$ PIPES buffer solution) followed by water $(1.80 \mathrm{~mL})$. The solution was stirred slowly at $200 \mathrm{RPM}$ and triethanolamine $(48 \mathrm{mg}, 0.326 \mathrm{mmol}$ ) was added, and the $\mathrm{pH}$ of the solution was monitored with a $\mathrm{pH}$ meter and adjusted to 7.6 with $8 \mathrm{~N} \mathrm{KOH}(30 \mu \mathrm{L})$. Manganese dichloride $(4.1 \mathrm{mg}, 0.033 \mathrm{mmol})$ was added, followed by sucrose $(632 \mathrm{mg}, 1.85 \mathrm{mmol}$ ), and the $\mathrm{pH}$ of the solution was kept between 7.3 to 7.8 by addition of $2 \mathrm{~N} \mathrm{KOH}$ solution as needed. The enzyme powders were added sequentially: DERARd3BB (1.8 mg); PNP-Rd5BB (2.6 mg); PPM-Rd3BB (13 mg); and SP (2.0 mg). After all enzymes dissolved, 2-FA, $(11,75 \mathrm{mg}, 0.49 \mathrm{mmol})$ was added. The $\mathrm{pH}$ of the suspension was adjusted with $2 \mathrm{~N} \mathrm{KOH}(6 \mu \mathrm{L})$ to 7.6 from 7.4. After heating the reaction to $35^{\circ} \mathrm{C}$, acetaldehyde- $2-{ }^{14} \mathrm{C}$ aqueous solution $(9,0.74 \mathrm{~mL}, 0.91$ $\mathrm{mmol}, 68 \mathrm{mCi} / \mathrm{mL}, 55 \mathrm{mCi} / \mathrm{mmol}$ ) was added. Finally, unlabeled islatravir API seeds $(5 \mathrm{mg})$ were added. The reaction vial was sealed, and the suspension was stirred at $35^{\circ} \mathrm{C}$ and monitored by HPLC. After 22 $\mathrm{h}$, the suspension was cooled to $5^{\circ} \mathrm{C}$ for 60 minutes and the crude product was collected by filtration. The crude product was washed with cold water $(2 \times 1.5 \mathrm{~mL})$ and dried under air to give crude $\left[{ }^{14} \mathrm{C}\right]$ islatravir monohydrate, $134 \mathrm{mg}$ with $99.0 \% \mathrm{RCP}$, in $54 \%$ yield based on limiting 2-FA. Two reactions with similar scale were conducted, and the crude product was combined and further purified with silica gel chromatography ( $80 \mathrm{~g}$ gold ISCO column) eluting with $0-20 \% \mathrm{MeOH}$ in $\mathrm{CH}_{2} \mathrm{Cl}_{2}$ to give the final purified product. $36.8 \mathrm{mCi}$ of $\left[{ }^{14} \mathrm{C}\right]$ islatravir (in $52 \mathrm{~mL}$ of EtOH) was obtained from $108 \mathrm{mCi}$ of the acetaldehyde-2${ }^{14} \mathrm{C}$ starting material through these two reactions in $34.1 \%$ radiochemical yield with $100 \% \mathrm{RCP}$ and $100 \%$ UV purity by RP-HPLC. Mass Spectral data was obtained under API-ES positive ionization mode and the specific activity was determined by LC-MS method as $51.3 \mathrm{mCi} / \mathrm{mmol}$.

An unlabeled batch of islatravir was synthesized using the same procedure as the above $\left[{ }^{14} \mathrm{C}\right]$ islatravir synthesis, and the purified product was subjected to total protein content testing. No quantifiable protein was detected, NQ (<385 PPM). This demonstrated the silica gel chromatography purification effectively removed the trace protein after the reaction. 


\section{Analytical data}

HPLC/ UV trace for authentic unlabeled islatravir by HPLC system 2

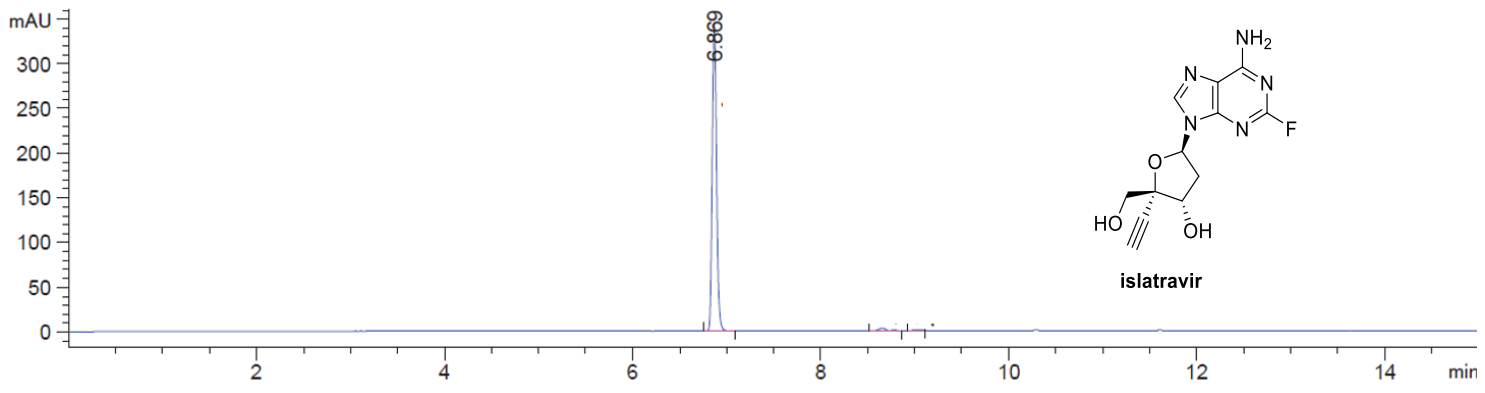

\section{Radio-HPLC/ Radioactivity trace for $\left[{ }^{14} \mathrm{C}\right]$ islatravir}

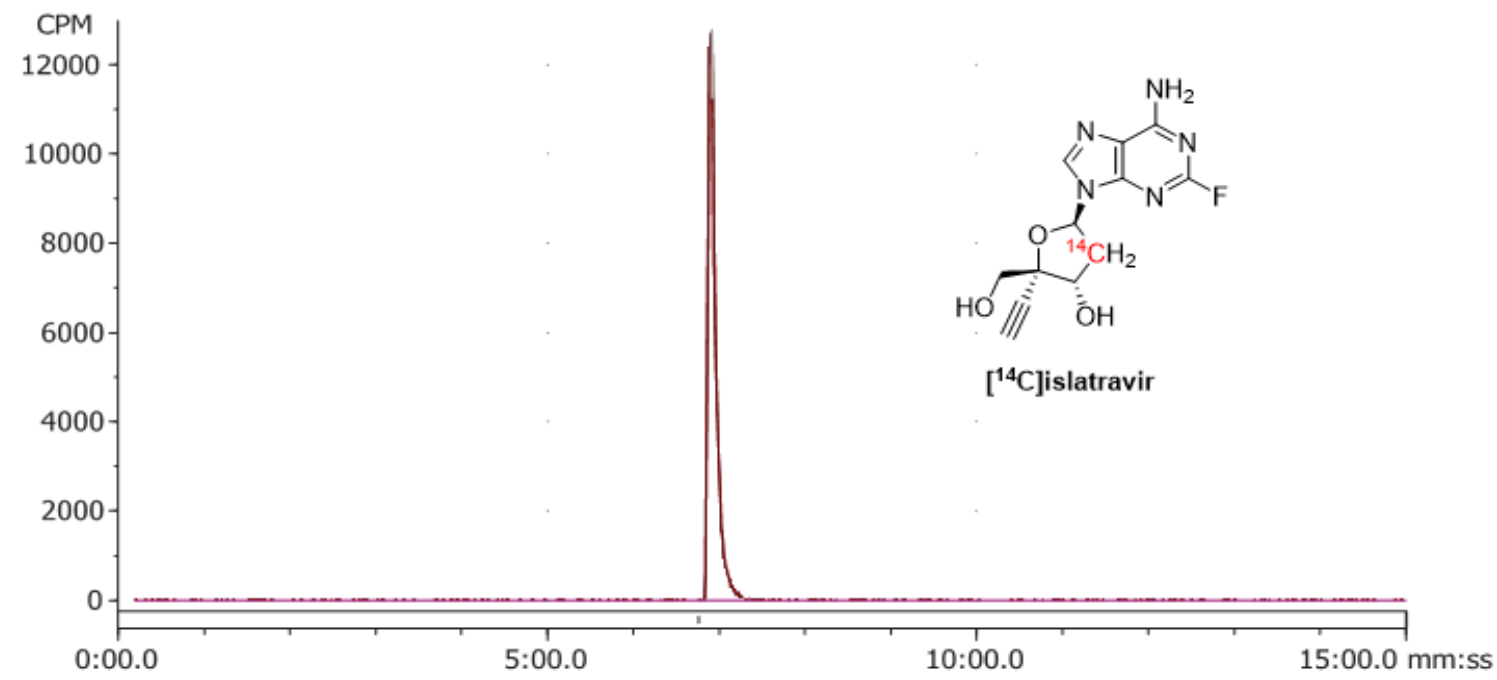

\begin{tabular}{lrrrrr} 
Regions: & ${ }^{14} \mathrm{C}$ & \multicolumn{1}{c}{ Detector: } & B-RAM & \\
\hline Name & $\begin{array}{r}\text { Start } \\
(\mathrm{mm}: \mathrm{ss})\end{array}$ & $\begin{array}{r}\text { End } \\
(\mathrm{mm}: \mathrm{ss})\end{array}$ & $\begin{array}{r}\text { Retention } \\
(\mathrm{mm}: \mathrm{ss})\end{array}$ & $\begin{array}{r}\text { Area } \\
(\mathrm{CPM})\end{array}$ & $\begin{array}{r}\% \text { ROI } \\
(\%)\end{array}$ \\
\hline Region 1 & $6: 45.5$ & $7: 21.0$ & $6: 55.0$ & 152208 & 100.00 \\
\hline 1 Peak & & & & 152208 & 100.00
\end{tabular}

Total Area:

160816 CPM

Average Background: $\quad 0$ CPM 


\section{MS data of $\left[{ }^{14} \mathrm{C}\right]$ islatravir and reference}
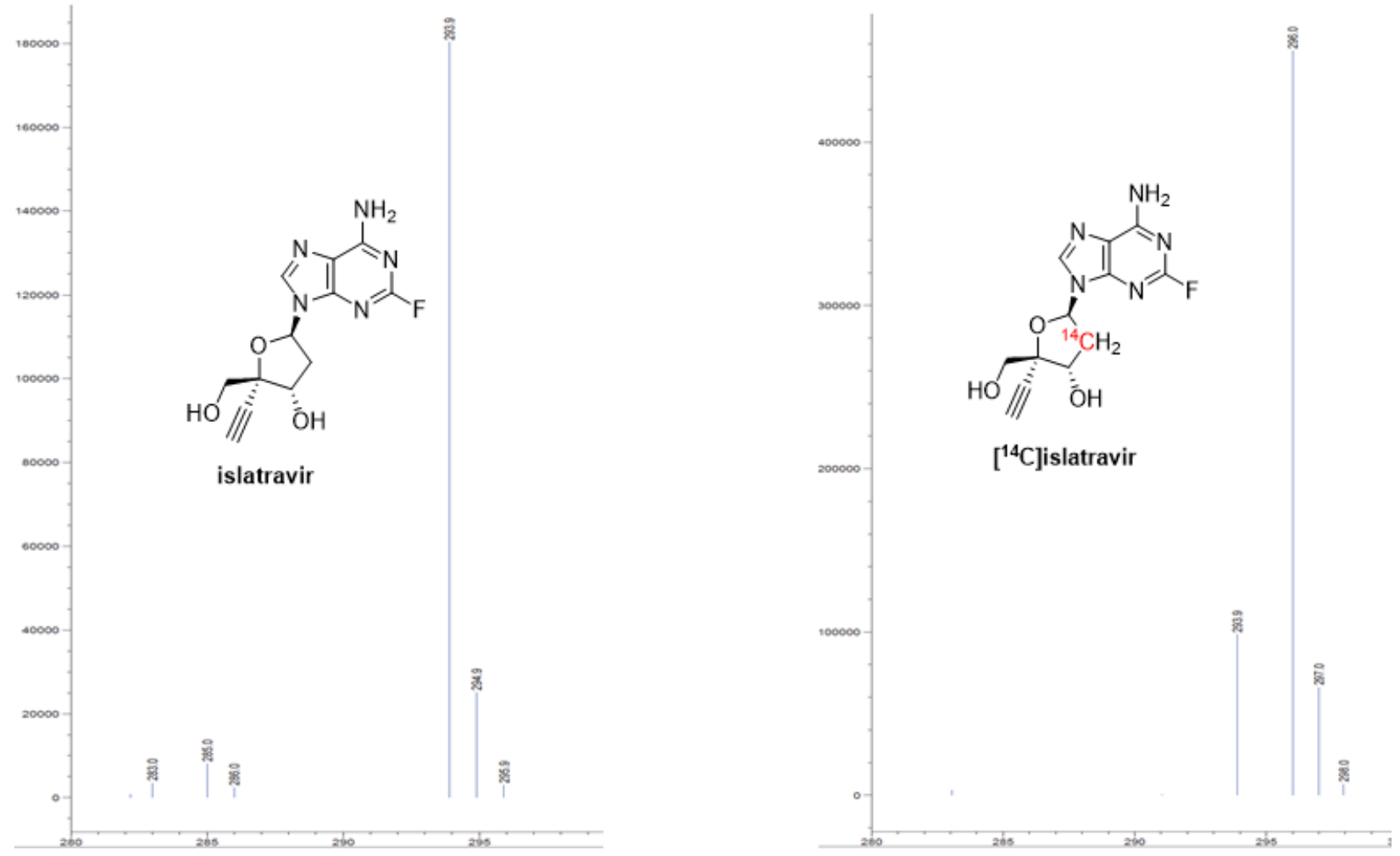


\section{Specific activity of $\left[{ }^{14} \mathrm{C}\right]$ islatravir which calculated from MS data}

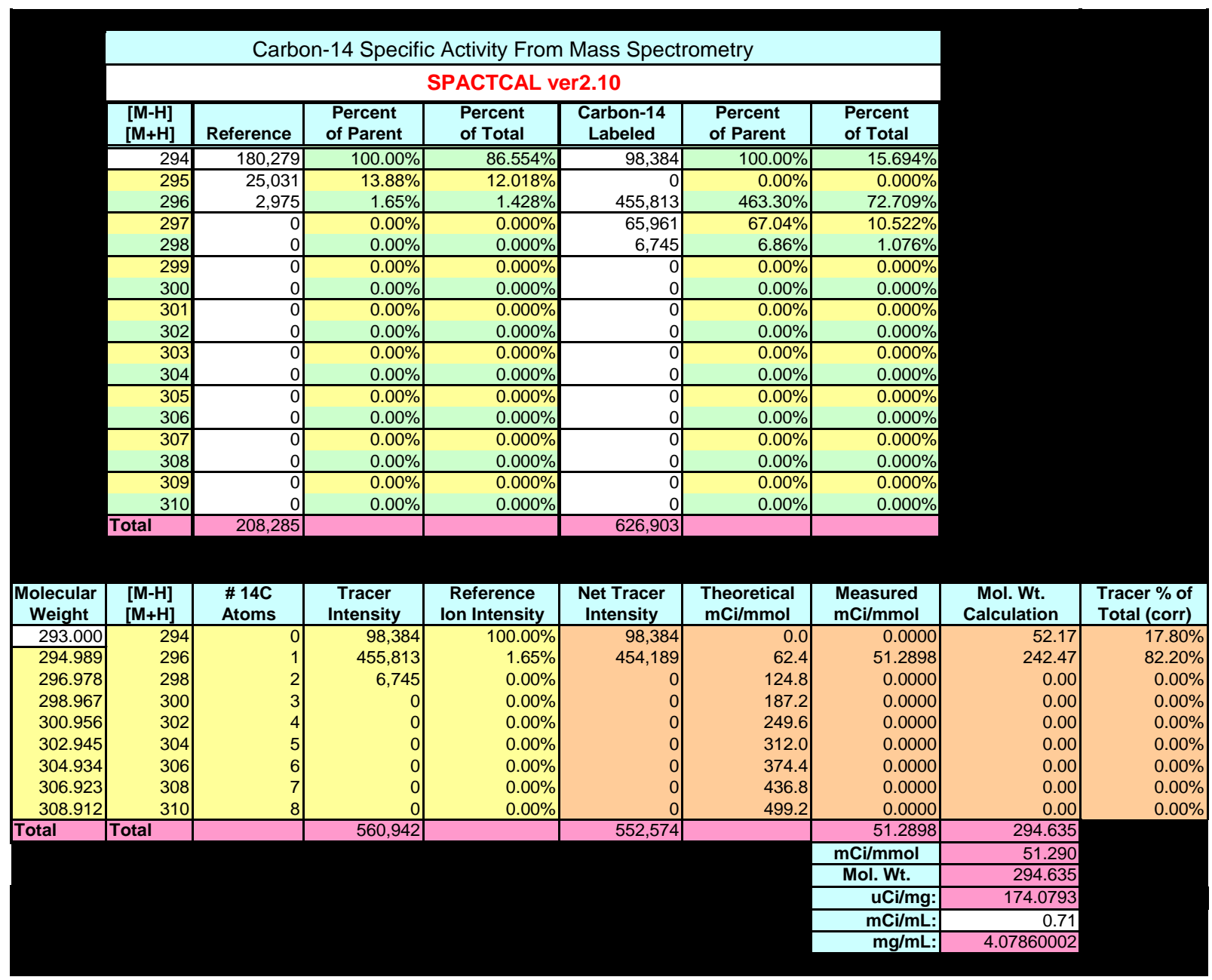

\section{References}

1. McLaughlin, M.; Kong, J.; Belyk, K. M.; Chen, B.; Gibson, A. W.; Keen, S. P.; Lieberman, D. R.; Milczek, E. M.; Moore, J. C.; Murray, D.; Peng, F.; Qi, J.; Reamer, R. A.; Song, Z. J.; Tan, L.; Wang, L.; Williams, M. J. Enantioselective synthesis of 4'-ethynyl-2-fluoro-2'-deoxyadenosine (EFdA) via enzymatic desymmetrization. Org. Lett. 2017, 19, 926-929.

2. Huffman M. A.; Fryszkowska, A.; Alvizo, O.; Borra-Garske, M.; Campos, K. R.; Canada, K. A.; Devine, P. N.; Duan, D.; Forstater, J. H.; Grosser, S. T.; Halsey, H. M.; Hughes, G. J.; Jo, J.; Joyce, L. A.; Kolev, J. N.; Liang, J.; Maloney, K. M.; Mann, B. F.; Marshall, N. M.; McLaughlin, M.; Moore, J. C.; Murphy, G. S.; Nawrat, C. C.; Nazor, J.; Novick, S.; Patel, N. R.; Rodriguez-Granillo, A.; Robaire, S. A.; Sherer, E.; Truppo, M. D.; Whittaker A. M.; Verma, D.; Xiao, L.; Xu, Y.; Yang, H. Design of an in vitro biocatalytic cascade for the manufacture of islatravir. Science 2019, 366 (6470), 1255-1259.

3. ${ }^{14} \mathrm{C}$-compounds are generally stored in ethanol solution at low temperature to slow down radiolytic decomposition.

4. NMR data for the ${ }^{14} \mathrm{C}$-labeled compounds is not available due to the limitation of handling ${ }^{14} \mathrm{C}$-labeled compounds in our NMR labs now. 